University of South Florida

DIGITAL COMMONS

Digital Commons @ University of

@ UNIVERSITY OF SOUTH FLORIDA

South Florida

KIP Monographs

KIP Research Publications

January 2012

\title{
Tzinacamoztoc, Possible Use of a Lava Tube as a Zenithal \\ Observatory Near Cantona Archaeological Site, Puebla, Mexico
}

Ramón Espinasa-Pereña

Ruth Diamant

Follow this and additional works at: https://digitalcommons.usf.edu/kip_monographs

\section{Recommended Citation}

Espinasa-Pereña, Ramón and Diamant, Ruth, "Tzinacamoztoc, Possible Use of a Lava Tube as a Zenithal Observatory Near Cantona Archaeological Site, Puebla, Mexico" (2012). KIP Monographs. 23.

https://digitalcommons.usf.edu/kip_monographs/23

This Book is brought to you for free and open access by the KIP Research Publications at Digital Commons @ University of South Florida. It has been accepted for inclusion in KIP Monographs by an authorized administrator of Digital Commons @ University of South Florida. For more information, please contact digitalcommons@usf.edu. 


\title{
TZINACAMOZTOC, POSSIBLE USE OF A LAVA TUBE AS A ZENITHAL OBSERVATORY NEAR CANTONA ARCHAEOLOGICAL SITE, PUEBLA, MEXICO
}

\author{
Ramón Espinasa-Pereña and Ruth Diamant
}

An arificial structure was discovered under a natural skylight inside Grutas de Tzinacamóztoc, in the vicinity of the archaeological site of Cantona. The structure is made up of piled rocks, defining a pentagonal enclosure with a central mound. Detailed measurements and computer modeling allowed tracing of the sunbeam path projected on the structure and on the cave floor, particularly for dates of astronomical and/or Mesoamerican calendrical importance. This corroborates the possible prehispanic use of this site as a complex and sophisticated gnomon.

Se descubrió una estructura artificial bajo un tragaluz natural en las Grutas de Tzinacamóztoc, cerca del sitio arqueológico de Cantona. La estructura consiste en un apilamiento de rocas que define un recinto pentagonal con un montículo central. Mediante medidas detalladas y modelación por computadora se pudo obtener la traza del haz de luz proyectada sobre la estructura y el piso de la cueva, en particular para fechas de importancia astronómica y/o calendárica ritual mesoamericana, corroborando el posible uso prehispánico de este sitio como un complejo y sofisticado gnomon.

7 The Grutas de Tzinacamóztoc are a series of considerably large lava tube caves located near the remains of the archaeological site of Cantona, in the state of Puebla, Mexico (Figure 1). They were first mentioned in the scientific literature by Virlet d'Aoust (1865). Later, in a study specifically dedicated to the caves, Haarmann (1910) described a mortar wall built inside the upper cave to prevent soil loss. The portion of the caves visited by Haarmann is no longer accessible, due to infilling of soil, but he did publish a sketch of the section he visited. Wittich (1921) describes the caves as being almost $2 \mathrm{~km}$ long

No other references have been found about these caves. In May 2006, members of Sociedad Mexicana de Exploraciones Subterráneas (SMES) and the Veracruz section of the Club Exploraciones de México A.C. (CEMAC) visited and surveyed the lava tube, producing a map that was published as part of the XII Symposium on Vulcanospeleology Field Trip Guidebook (Espinasa-Pereña 2008).
During that survey, an area covered by a "ring" of small rocks under a skylight was noted. On further inspection made in July of that same year, during the actual fieldtrip, the volcano-speleologists considered that the structure was of artificial origin.

A recent visit to the Xochicalco archaeological site with its famous zenithal observatory (CornejoRodríguez et al.2011) suggested to us a similar function for the structure, considering also its proximity to the huge prehispanic urban center of Cantona.

The Cantona archaeological site was discovered in the middle of the nineteenth century by Henri de Saussure (1855). According to Ferriz (1985), the original name was Caltónac, which means House of the Sun. This spectacular site had not been excavated until recently (García Cook and Merino Carrión 1998). It is believed to be one of the largest urban centers yet discovered in Mesoamerica, and covers 14.5 square kilometers divided into three urban areas (Figure 2). The site contains a network of over 4,000 cobblestone roads,

Ramón Espinasa-Pereña Centro Nacional de Prevención de Desastres, México, D.F. (respinasa@cenapred.unam.mx,

respinasa@yahoo.com.mx)

Ruth Diamant $\mathbf{m}$ Departamento de Física, Universidad Autónoma Metropolitana Iztapalapa, México, D.F.

(ruth@xanum.uam.mx)

Latin American Antiquity 23(4), 2012, pp. 585-596

Copyright (C2012 by the Society for American Archaeology 


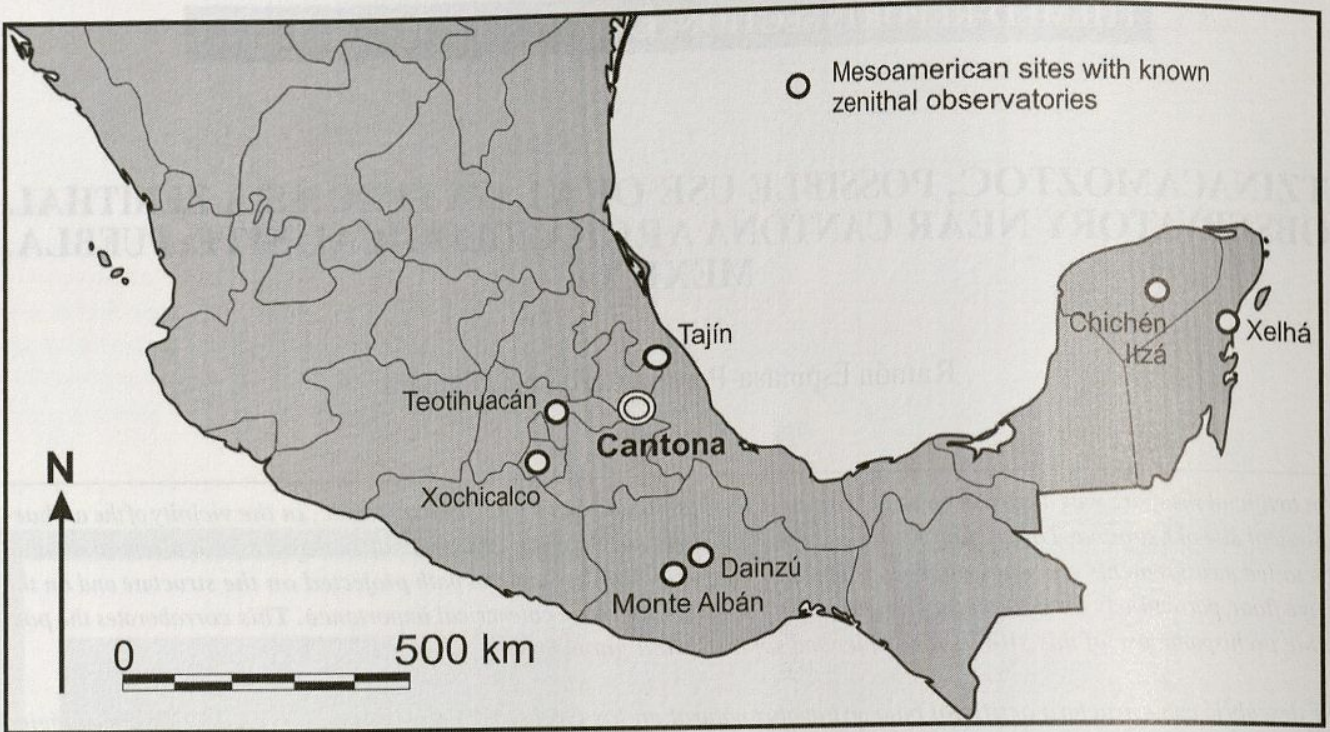

Figure 1. Location map of the archaeological sites where zenithal observatories have been reported, and location of the city of Cantona.

more than 7,000 individual patios or residences, 27 ball courts, an elaborate acropolis with many ceremonial buildings and temples, and several secondary or neighborhood ceremonial centers (García Cook 2004; García Cook and Martínez Calleja 2008). These remarkable buildings were assembled by placing carved stones one atop the other, without any stucco covering or cement mortar being used in their construction. The buildings are adjusted to the topography of the thick lava flow on which they were built, and take advantage of its steep slopes (García Cook and Merino Carrión 1998). Cantona was contemporary to the more famous Teotihuacán and Cholula cultures during the Classic period but also coexisted with Xochicalco during the Epiclassic. Its importance was directly related to the commercial exploitation of the obsidian deposits in nearby Oyameles-Zaragoza (Ferriz 1985). It was abandoned five hundred years before the conquest.

The well-documented obsession of Mesoamerican cultures with the study and recording of the passage of time (Aveni 1991, 2001; Carot and Hers 2011; Iwaniszewski 1999; León-Portilla 1986; Sprajc 2000a) resulted in the construction of numerous devices to keep track of the solar cycle (Galindo Trejo 2001), such as horizon calendars (Montero García 2004, 2011; Morante López 1990), architectural alignments (Casares Contreras 2001;
Sprajc 2000b, 2001), and zenithal observatories (Anderson 1981; Moragas Segura 1998; Morante López 1995, 2001, 2010). Of these, the least abundant are the last mentioned, and only seven sites have been documented previously. Zenithal observatories could be used to determine the solar zenith passage, a very important phenomenon in Mesoamerican ideology. For Cantona's latitude, the first solar zenith passage of the year falls close to May 17, just previous to the beginning of the rainy season. Other important solar dates, like the summer solstice, could be determined as well with the use of zenithal observatories, therefore becoming an aid in correlating the calendar.

\section{Methodology}

The Tzinacamóztoc lava tube caves were surveyed by the first author and members of SMES and CEMAC Veracruz to a grade 5 b of the British Cave Research Association standards (Ellis 1976). This means that fixed survey stations were set along the passages, between which length (to the closest centimeter) was measured with a nylon tape; azimuth and slope (to the closest $1 / 2$ degree) were measured with Suunto instruments. Occasional inverted readings were made in an attempt to detect any magnetic anomalies, as suggested by Ellis (1976), but no evidence was found of their presence. Distance 


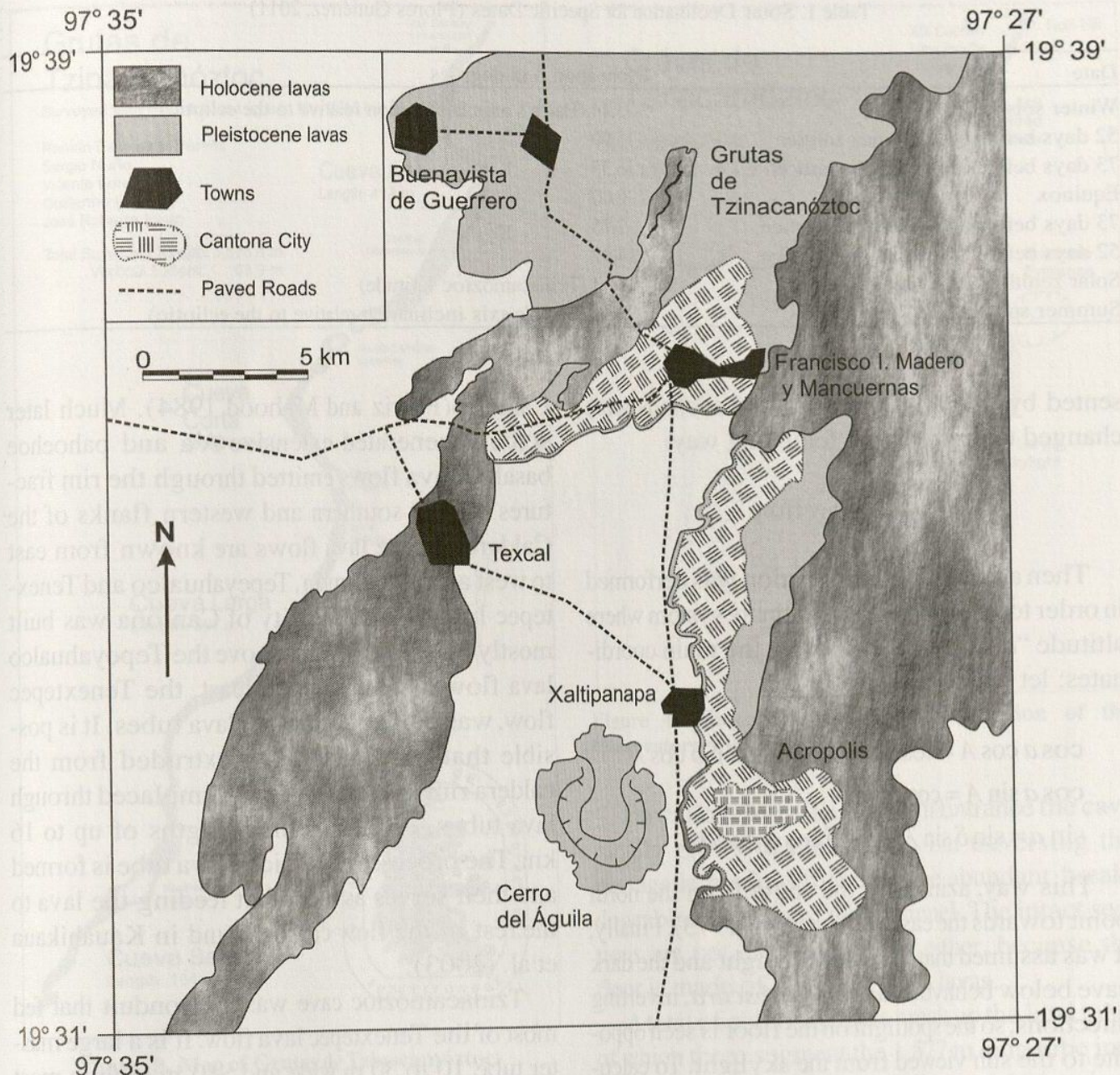

$97^{\circ} 35^{\prime}$

Figure 2. Map of the City of Cantona, with the Tepeyahualco and Tenextepec lava flows indicated, and the location of the Tzinacamóztoc lava tube.

to walls, floor, and ceiling were estimated for each station. Plan, profile, and cross-section sketches were simultaneously made, in which lava tube features were drawn and located. Survey data were processed using the COMPASS and CaveXO computer programs.

The actual observatory structure was sketched following the recommendations in Brennan (1973), Davies (1987), and Sease (1994). The "Tipi Quick" mapping technique (Ministry of Tourism, Parks, Culture and Sport 2008) was also used. A plumb was used to mark a point right below the skylight; this point was found to be atop the largest stone on the central mound and was used as the central station. A tripod was placed above this central station to raise it above any of the observatory structure features, and from it, a series of radial horizontal lines were placed. The geographic azimuth for these lines was recorded with a Brunton compass. The horizontal distance to the features (edges and corners of the structure, a deep crack in the floor, and the surrounding major breakdown blocks) and their vertical displacement below the horizontal line were measured with a plastic survey tape.

To determine the path of the sun's spotlight on the cave floor and the observatory structure during specific days, a model similar to Montenbruck and Pfleger's (1994) was used: First, the sun's position was determined in a rotating equatorial coordinate system. Declination was chosen as the first coordinate, here represented by " $\delta$ " (Table 1$)$. Solar hour angle was used for the second one, repre- 
Table 1. Solar Declination for Specific Dates (Flores Gutiérrez, 2011)

Date

Winter solstice

52 days before or after winter solstice

73 days before or after winter solstice

Equinox

73 days before or after summer solstice

52 days before or after summer solstice

Solar zenith passage day

Summer solstice
Declination $\delta$ in degrees

-23.44 (Earth's axis inclination relative to the ecliptic)

$-13.90$

$-6.35$

0.00

7.75

14.87

19.63 (Tzinacamóztoc latitude)

23.44 (Earth's axis inclination relative to the ecliptic) sented by " $\varphi$ ". Hours, minutes and seconds were changed to degrees in the following way:

$$
\phi=\frac{360}{24} \times \text { day time }
$$

Then a rotational transformation was performed in order to get a horizontal coordinate system where altitude " $a$ " and azimuth " $A$ " are the main coordinates; let " $\lambda$ " be the latitude:

$$
\begin{aligned}
& \cos a \cos A=\cos \delta \cos \phi \sin \lambda+\sin \delta \cos \lambda \\
& \cos a \sin A=\cos \delta \sin \phi \\
& \sin a=\sin \delta \sin \lambda-\cos \delta \cos \phi \cos \lambda
\end{aligned}
$$

This way, azimuth is the angle from the north point towards the east as in Norton (1973). Finally, it was assumed that the small skylight and the dark cave below behave as a camera obscura, inverting directions, so the spotlight on the floor is seen opposite to the sun viewed from the skylight. To calculate the horizontal distance " $d$ " from the spotlight center to the central topographic station a trigonometric relation was needed:

$$
d=\frac{h}{\tan a}
$$

Where " $h$ " is the height of the skylight above the floor. The azimuth direction " $\mathrm{A}_{\mathrm{z}}$ " of the spotlight relative to the central station is:

$$
A_{z}=A \pm 180^{\circ}
$$

\section{The Tzinacamóztoc Lava Tube}

The Los Humeros Caldera was formed by the collapse of a pre-existing stratovolcano due to the eruption of very large pyroclastic flows, which formed the Xaltipan Ignimbrite $.56 \pm .21$ million years ago, distributed mostly to the north of the
Caldera (Ferriz and Mahood 1984). Much later activity generated extensive A'a and pahoehoe basaltic lava flows emitted through the rim fractures on the southern and western flanks of the Caldera. These lava flows are known from east to west as the El Limón, Tepeyahualco and Tenextepec lava flows. The city of Cantona was built mostly on the edges and above the Tepeyahualco lava flow. One of them at least, the Tenextepec flow, was emplaced through lava tubes. It is possible that other lava flows extruded from the caldera rim fractures were also emplaced through lava tubes, explaining their lengths of up to 16 $\mathrm{km}$. The processes by which a lava tube is formed and then serves as a conduit feeding the lava to the rest of the flow can be found in Kauahikaua et al. (2003).

Tzinacamóztoc cave was the conduit that fed most of the Tenextepec lava flow. It is a large master tube 10 to $30 \mathrm{~m}$ wide and $>10 \mathrm{~m}$ high in most places. Haarmann (1910) calculated its length at about $500 \mathrm{~m}$. Finding stream deposits in the cave floor, he proposed that the cave had formed when the lava flow covered a flowing stream, which evaporated and the gas pressure pushed the lava flow upwards leaving a void underneath. Wittich (1921) suggests that the stream deposits seen by Haarmann entered the cave after it solidified. He concludes that the cave formed by the solidification of the flow crust, but with liquid lava remaining inside. After the lava broke the crusted front, it flowed onwards, leaving a void behind.

The original entrance, as described by Haarmann (1910), is now completely filled by stream deposits that originated on the fields that partially cover the upper end of the lava flow. Haarmann describes the passage, now inaccessible, as being up to $10 \mathrm{~m}$ wide and $15 \mathrm{~m}$ high. He also mentions that the upper portion of the cave ends at a nine- 


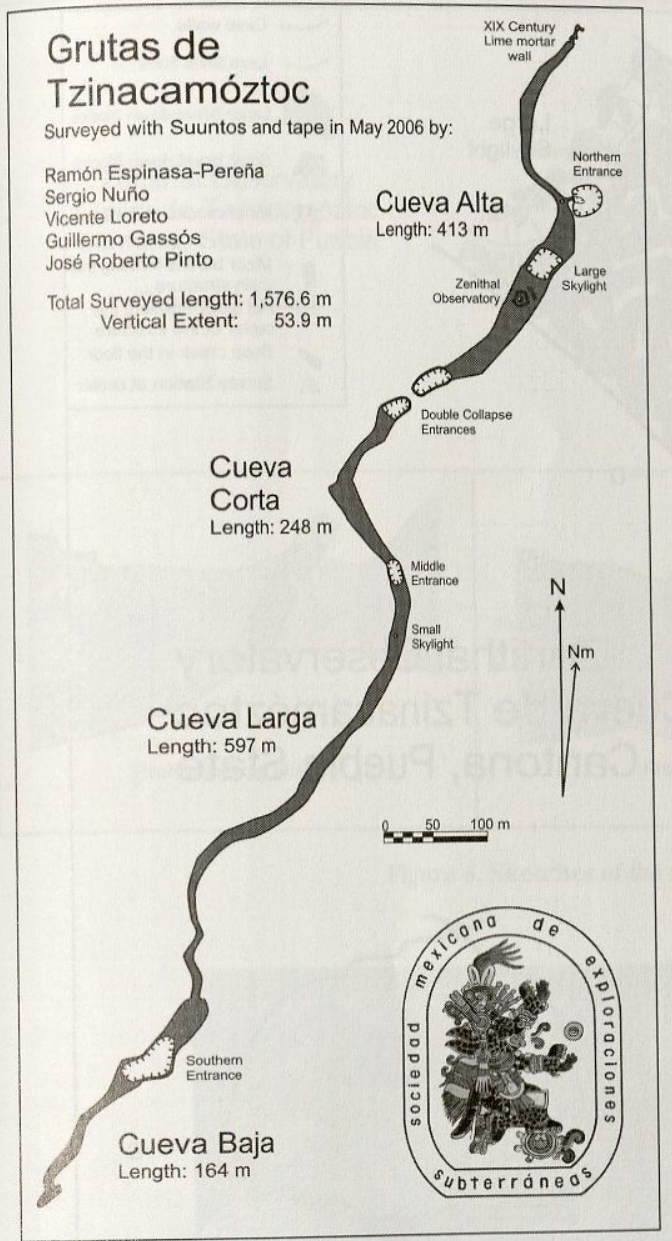

Figure 3. Map of Grutas de Tzinacamóztoc.

teenth-century mortar wall that was built to prevent soil loss, since a surface stream entered the original upper entrance. The lower side of the wall is accessible through another, lower entrance (the Northern Entrance on the map). This entrance is a small hole at the bottom of a $20 \mathrm{~m}$ wide surface depression whose western wall is vertical. We believe this depression was an open skylight during activity. It gives access to a small shelf above the main canyon-shaped passage.

Between the Northern Entrance and the artificial wall the passage is covered in soot from torches. The floor is flat and mostly covered in sandy mud deposits. Sometime in the last twenty years, somebody dug a hole through the artificial wall, probably believing it hid a treasure. The completely sediment-filled passage beyond is accessible through the dug tunnel for about $15 \mathrm{~m}$.

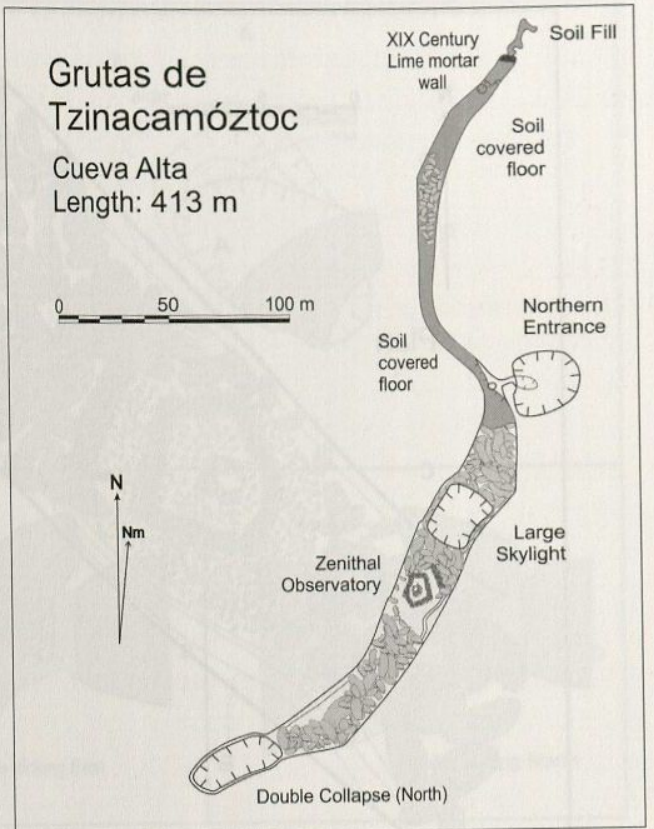

Figure 4. Map of Cueva Alta and location of the Observatory within it.

Downflow from the Northern Entrance the cave rapidly grows in dimensions, but traversing the passage is made difficult by the abundant breakdown blocks on most of the tunnel. The intact sections are not easily traversed either, because the floor is made of very rough A'a lavas.

A total of eight skylights break up the lava tube, of which three segment the $1,577 \mathrm{~m}$ long tube into four caves, $413 \mathrm{~m}, 248 \mathrm{~m}, 597 \mathrm{~m}$ and $164 \mathrm{~m}$ long (Figure 3).

\section{Description of the Observatory}

The structure that we have identified and have called the observatory is inside the upper cave (Cueva Alta, Figure 4). Cueva Alta is a tube segment which presently is $413 \mathrm{~m}$ long but was probably almost a kilometer long before the construction, of the mortar wall during the nineteenth century. The cave can presently be entered by walking through two entrances, both located some hundred meters from the actual observatory, by traversing breakdown-floored passages. The breakdown itself consists of large meter-sized blocks. North from the Northern Entrance the passage floor is covered by stream-transported soil deposits until the lime mortar wall is reached. This 


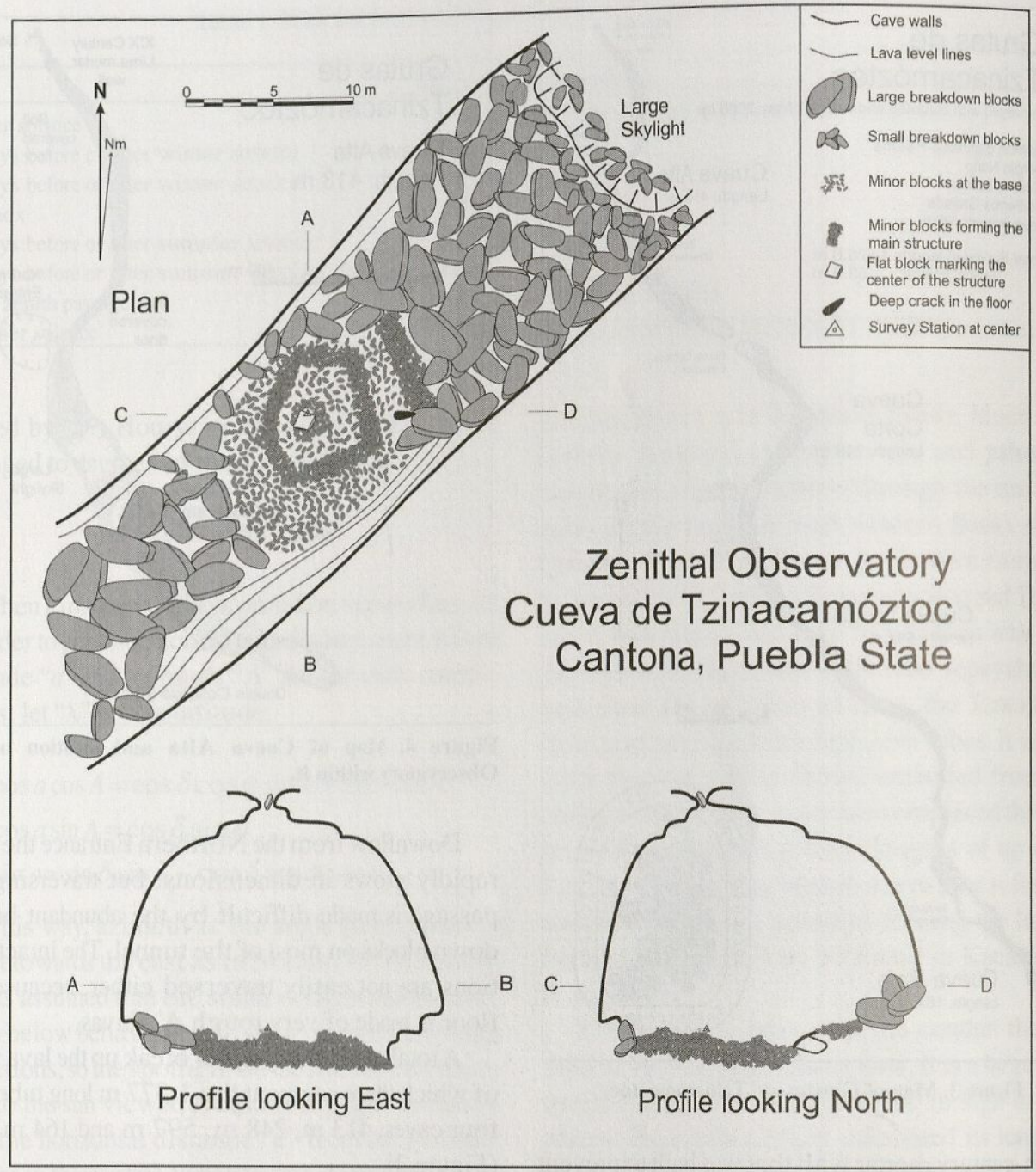

Figure 5. Plan and Profile views of the Zenithal Observatory.

soil floor is probably several meters thick above the original breakdown floor.

About 30 m northeast of the actual observatory, there is a large collapse skylight with vertical or overhanging walls that prevent its use as an entrance without the help of ladders or ropes. From this opening, light enters the cave and illuminates most of the area covered by the structure. The passage in this area is over $20 \mathrm{~m}$ wide and 10 to $15 \mathrm{~m}$ high.

The area where the observatory is built is relatively free of breakdown blocks. Remains of levees and other primary structures formed by the flowing lava can be identified along the base of the tube walls.

\section{The Observatory}

The structure is based on a pile of small rocks that fill the space between much larger breakdown blocks. On top of this pile lie the remains of what must have been a walled structure, with a pentagonal pattern and with a central mound (Figure 5). The central mound is located precisely beneath a small natural aperture on the tube's ceiling that allows sunlight in (the observatory skylight, described below).

At the top of the central mound there is a basalt slab larger than most of the rocks forming the structure. We called this rock the "altar," but its original function and placement is not known. Three or four other large rocks could be pieces of the larger 


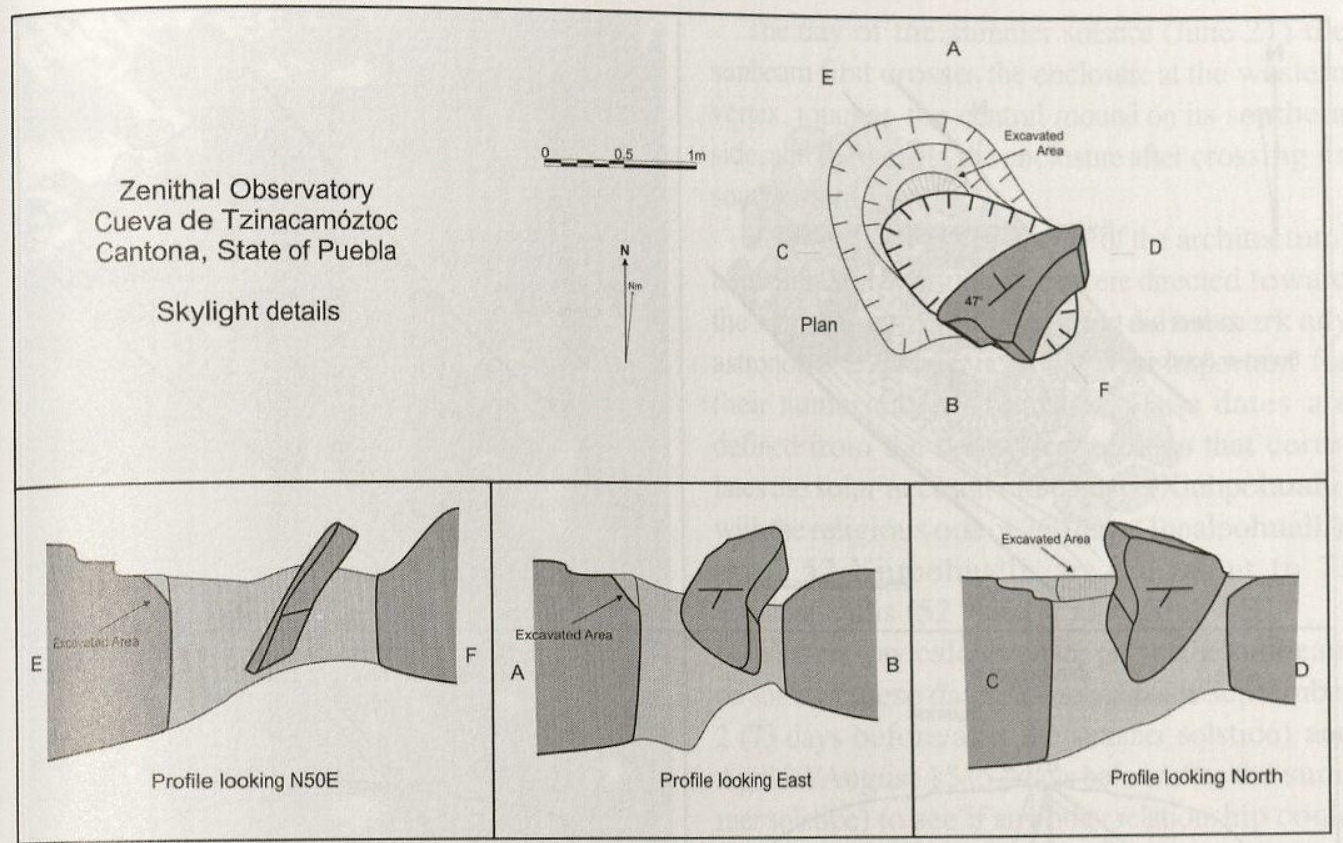

Figure 6. Sketches of the skylight and its capstone.

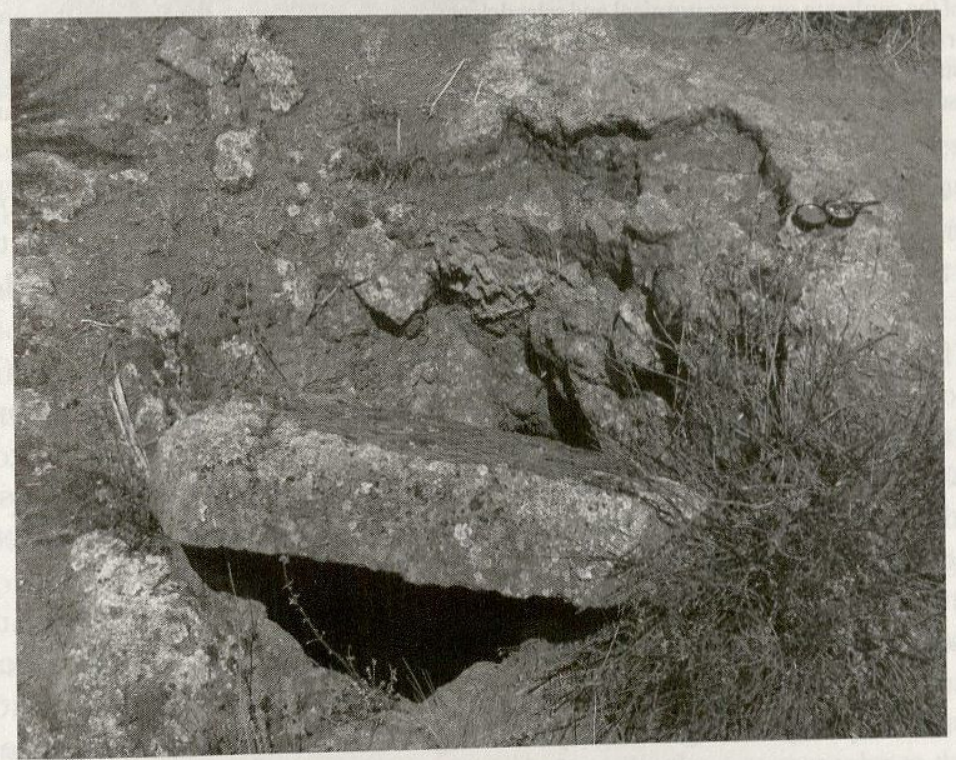

Figure 7. Photo of the Skylight and its Capstone. The Brunton compass at right is pointing towards geographic north.

slab. The remains of a second wall are located east of the small enclosure and cover some of the larger breakdown blocks at its southern end.

The walled structure is similar to the tetzacualcos of Montero (2004) in the sense that they are enclosures made by placing stones one atop the other, without any stucco covering or cement mortar being used in their construction. Nevertheless, no relation with the tetzacualcos is suggested, since this is the style of construction of most if not all the buildings in Cantona. Another characteristic of Cantona also shared by this structure is the lack of 


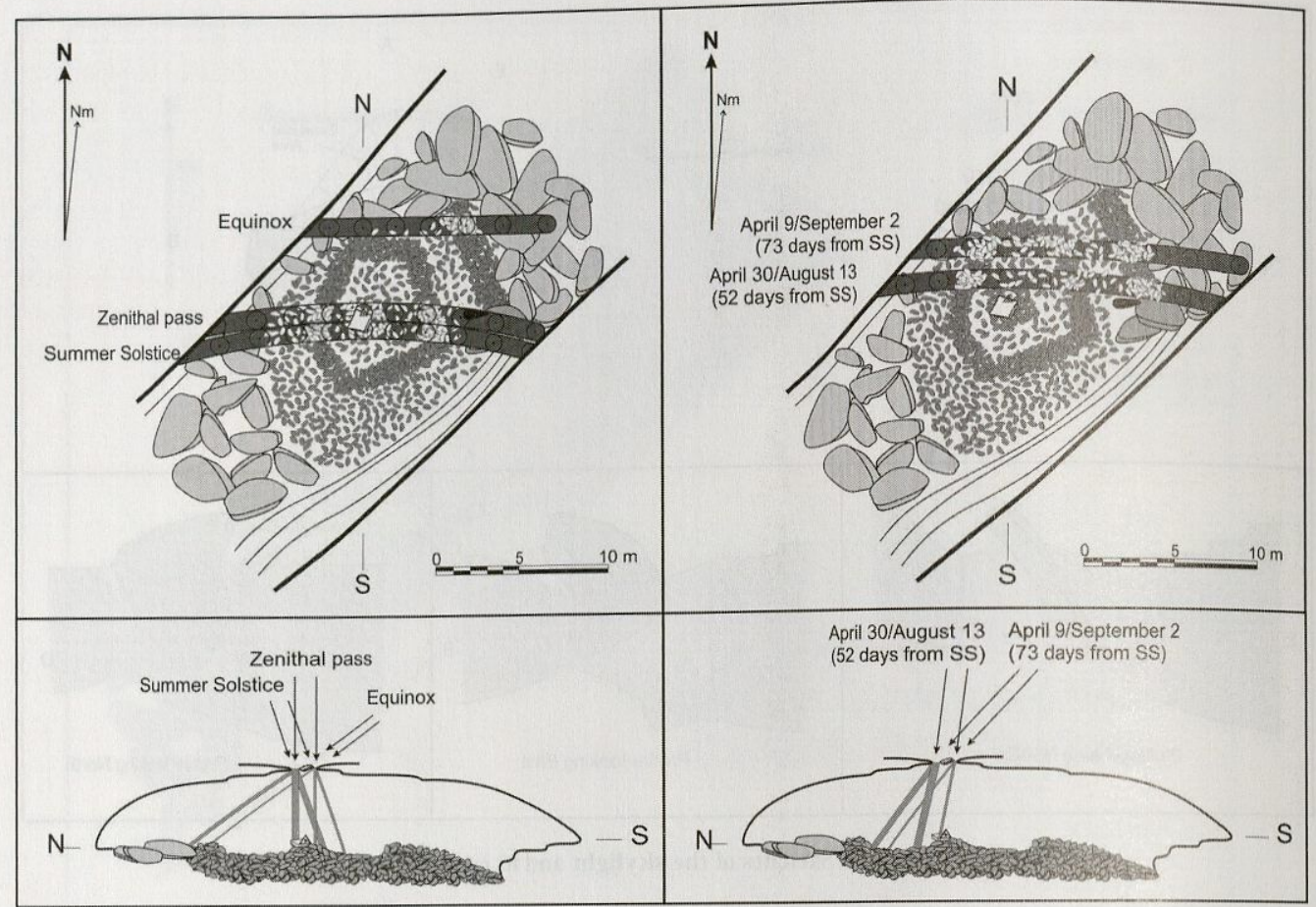

Figure 8. Paths of the sunbeam on astronomical and calendrical dates. Notice that on the Equinox the path is almost parallel with the northern wall of the enclosure, that on the Zenithal pass it hits the central mound and the deep crack on the wall, while on the summer solstice it passes by the eastern and western corners of the structure. On dates 52 days before/after the summer solstice, the sunbeam bisects the northwestern and eastern walls of the enclosure.

symmetry. No entrance to the walled enclosure can be discerned from the remains, although the lowermost point is at the eastern side, towards the Large Skylight.

The rocks forming the enclosure and central mound are much smaller in size than the big breakdown blocks naturally found inside the cave. They are of similar shape and size to the ones making up the nearest mounds of Cantona City. They were probably brought into the cave by the builders of the structure from an a'a lava flow to the west of the cave's pahoehoe lava flow. The rocks that make up the enclosure and central mound were not moved or altered in any way during this study.

\section{The Skylight and its Capstone}

The observatory skylight, under which the observatory is located, must have been open during the lava flow activity, as evidenced by levees and lava level marks visible from below. This would explain the lack of breakdown blocks underneath it, which would have been transported down the tube by the flowing lava. At least three other skylight entrances to Tzinacamóztoc show evidence of having been open during lava flow activity, but the rest probably collapsed after the end of volcanic activity (Espinasa-Pereña 2008).

The observatory skylight itself (Figures 6 and 7) is an elliptical hole with its major axis oriented NW-SE and measuring $1.5 \mathrm{~m}$ long by $1 \mathrm{~m}$ wide. The northern edge of the hole presents what we think are chisel marks that could be evidence of some work to reshape the hole.

The skylight is covered by a $1.5 \mathrm{~m}$ long by $1 \mathrm{~m}$ wide and $20 \mathrm{~cm}$ thick slab of basaltic rock that was intentionally placed on top of the hole. Considering its dimensions and the average density of basalt $\left(3 \mathrm{~g} / \mathrm{cm}^{3}\right)$, its weight must be close to a ton. This slab is located so that it diminishes the actual size of the major sunlight beam entering the cave below, splitting it in two. This slab is oriented SW-NE and is presently placed with a dip of $47^{\circ}$ to the NW.

\section{Paths of the Sun on Specific Dates}

As explained in the methodology section, the sun's horizontal coordinates at specific dates and times, 


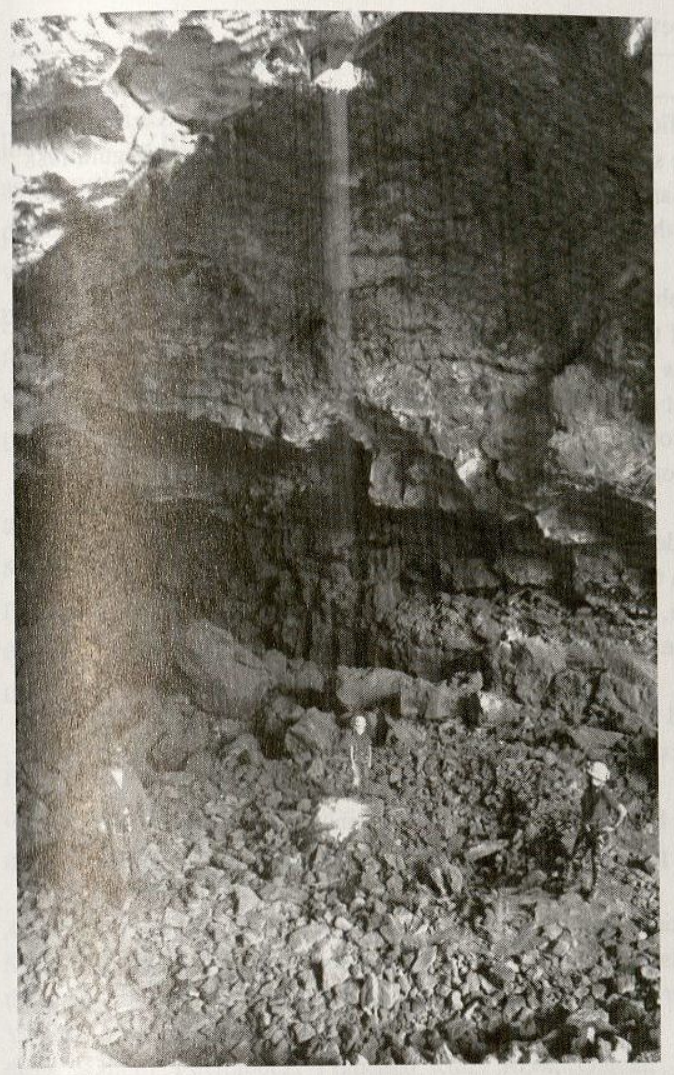

Figure 9. Photo of the sunbeam hitting the Central Mound, with people standing on the northeastern and southern corners of the enclosure. View towards the west.

at intervals of 30 minutes, were computed. From these data, positions of the sun spotlight on the cave floor and observatory were inferred. These positions were pinpointed on the map, which allowed us to draw the path traced by the sunlight along the day. We first calculated the paths for astronomically significant days (Figure 8).

The day of the spring equinox (March 21) the sunbeam travels parallel to the northern wall of the enclosure but just outside of it. It is possible that on the day of the mathematical equinox (March 23 and September 20, the middle day between the two solstices), and with the enclosure at its original height, the sunbeam could have illuminated the top of this wall.

On the days of solar zenith passage (May 17 and July 24), the sunlight beam enters the enclosure along its western "wall," hits the "altar" stone in the central mound (Figure 9), exits the enclosure along the eastern "wall," and then illuminates a deep crack on the cave floor.
The day of the summer solstice (June 21) the sunbeam first crosses the enclosure at the western vertex, touches the central mound on its southern side, and then exits the enclosure after crossing its southeastern vertex.

It is well known that many of the architectural alignments in Mesoamerica were directed toward the sunrise or sunset on dates that did not mark any astronomical phenomena but were important for their numerical relationships. These dates are defined from the calendrical equation that correlates the solar account of 365 days (Xiuhpohualli) with the religious one of 260 days (Tonalpohualli), where 52 Xiupohuallis are equivalent to 73 Tonalpohuallis $(52 * 365=73 * 260)$.

We therefore calculated the path of the sunbeam on some of these dates, namely April 9/September 2 (73 days before/after the summer solstice) and April 30/August 15 (52 days before/after the summer solstice) to see if any other relationship could be discerned (Figure 8):

For the dates situated 73 days before or after the summer solstice the sunbeam would have hit the base on the northern wall of the enclosure, and would have dissected the second eastern wall right in the middle.

The path of the sunbeam on dates 52 days before or after the summer solstice intersects both the western and eastern walls of the enclosure at their middle points, and would also intersect the southern end of the second eastern wall. On this date also, the smaller sunbeam would hit the "altar stone" on the central mound.

The winter solstice, and also those dates 52 and 73 days before/after the winter solstice were not plotted, as the sunbeam would not have reached the floor of the cave nor the structure itself, but instead would have traced a path on the northern wall of the cave, where no markers were identified. Other calendrical dates associated with numerical relationships, such as April 30/August 13 (65 days before/after the summer solstice, the division of the Tonalpohualli into four equal parts), might also be indicated in the studied observatory and could be recognized after its reconstruction and a more detailed study.

\section{Discussion}

A zenithal observatory is here considered as any 
Table 2. Zenithal Observatories Previously Known in Mesoamerica.

\begin{tabular}{ll}
\hline Site & Description \\
\hline Teotihuacán & $\begin{array}{l}\text { At least three and possibly up to seven artificially excavated caverns. The two } \\
\text { that have been studied in detail, were made so as to allow the entrance of sun- } \\
\text { light to mark specific dates } 73 \text { days before and after the winter solstice. The } \\
\text { solar zenith passage day is also marked by the vertical rays. }\end{array}$ \\
Xochicalco & $\begin{array}{l}\text { An artificial cave which has two different observatories, one of them carefully } \\
\text { blocked during a prehispanic remodeling of the structures above the site, the } \\
\text { other still functioning. This last one consists of a narrow and almost vertical } \\
\text { tube, carefully constructed to allow sunlight all the way to the cavern floor } \\
\text { only } 52 \text { days before and after the summer solstice. This } 105 \text { day interval } \\
\text { includes the two solar zenith passages, of course. }\end{array}$
\end{tabular}

Monte Albán An artificial chamber and pit were built under the stairs of Building P. It was constructed to mark the entrance of the Sun 65 days before and after the summer solstice and on the solar zenith passage. A similar structure under Building $\mathrm{H}$ has collapsed and cannot be studied properly.

Dainzú

A pit and chamber similar to the ones found in Monte Albán was discovered in this nearby site, but has not been properly excavated or studied.

References

Soruco Saenz 1991

Moragas Segura 1988

Morante López 1995

Morante López 2001

Anderson 1981

Morante López 1995

Morante López 2001

Morante López 1995

Morante López 2001

Morante López 1995

Morante López 2001

Tajín

The internationally famous and emblematic Pirámide de los Nichos contains a pit that goes all the way from the top of the pyramid to its base and was used

Morante López 2010 to mark dates:

- 73 days before and after the winter solstice,

- 52 days before and after the summer solstice,

- 10 days before the first and 10 days after the second solar zenith passage,

- the two solar zenith passages and

- the summer solstice.

Chichen Itzá

The pyramid known as El Osario contains a pit similar to the one in Tajín,

Krickeberg 1977 except that it enters a natural cave under the pyramid. It has not been studied properly for its calendrical properties.

Morante López 2010

Xelhá

A natural cave which had an altar that was lighted by the Sun through a sky-

Morante López 1995 light, on days near the solar zenith passage and the summer solstice.

Unfortunately the altar was vandalized and no proper studies of the calendrical properties of this site have been made.

covered space (underground or inside a building), with a hole in the ceiling that allows sunlight to enter such space on certain dates, mainly those close to the solar zenith passage. To date, seven sites with zenithal observatories in Mesoamerica have been identified and described at least partially in the literature (Table 2).The most primitive of these observatories are the ones in Teotihuacán, while the most complex, precise, and elaborate are the ones in Xochicalco, Monte Albán, and especially Tajín (little can be said about the one in Chichen Itzá). The Xelhá observatory is the one which, from its description, most closely resembles the Tzinacamóztoc site and its functions.
Sprajc (2000a) suggests that Mesoamerican astronomer-priests were well aware that their complex calendars did not keep pace with the tropical year, so to be able to predict the coming of important astronomical phenomena and the adequate dates for agricultural activities they needed precise solar "calendars" such as simple horizon markers, architectural alignments or the more sophisticated zenithal observatories.

No pottery, obsidian flakes or any other evidence of prehispanic traffic was found inside the caves, so the age of the Tzinacamóztoc Observatory is unknown. 


\section{Conclusions}

The structure found beneath a natural skylight inside the Tzinacamóztoc cave was probably built as azenithal observatory by the people of the nearby prehispanic urban center of Cantona. Its objective was probably to help track the passage of time and predict the arrival of important astronomical phenomena, such as the zenithal pass or the summer solstice, as well as dates of agricultural and/or ritual calendrical importance.

Precise mapping and computer modeling allowed us to demonstrate that at least the summer solstice, the zenithal pass days, calendrical dates marking the ritual division of the year, and the equinox, could have been determined with the use of this carefully constructed instrument.

It is possible that the Capstone partially blocking the skylight was placed there on purpose, both to get a smaller and more focused beam of light and/or to split the sunbeam in two.

Acknowledgments. We would like to thank the members of SMES and CEMAC who helped with the cave surveys and the mapping of the structure, especially Sergio Nuño, Vicente Loreto and Guillermo Gassos. We would also like to thank Manuel Fernández, Francisco Ruíz, Rosa García, Labná Fernández, Saasil Fernández and Ramón Espinasa Closas for their company while studying the observatory and for their thoughtful comments, and Dolores Soto, who gave us access to her library and helped us locate obscure references. The comments and suggestions of our editors and three anonymous reviewers helped improve this paper substantially. Finally, we would like to acknowledge the enthusiasm of Sofía Espinasa Diamant for exploring caves and science in general.

\section{References Cited}

Anderson, Neal S.

1981 The Solar Observatory at Xochicalco and the Maya Farmer's Almanac. Archaeoastronomy 4(2):22-25.

Aveni, Anthony F.

1991 Observadores del cielo en el México antiguo. Fondo de Cultura Económica, Mexico City.

2001 Skywatchers, a Revised and Updated Versión of Skywatchers of Ancient Mexico. University of Texas Press, Austin.

Brennan, Louis A.

1973 Beginner's Guide to Archaeology. Dell Publishing Company, New York.

Casares Contreras, Orlando Josué

2001 Una revisión arqueoastronómica de la Estructura 1Sub de Dzibilchaltún, Yucatán. Temas Antropológicos 23(2):5-19.

Carot, Patricia, and Marie-Areti Hers

2011 La Mesoamérica septentrional y el saber astronómico teotihuacano. In Legado astronómico, edited by Daniel J.
Flores Gutiérrez, Margarita Rosado Solís and José Franco López, pp. 183-195. Instituto de Astronomía, Universidad Nacional Autónoma de México, Mexico City.

Cornejo-Rodríguez, Alejandro, Sergio Vázquez-Montiel, Fermín Salomón Granados-Agustín, Alejandro CornejoRodríguez, David Gale, Ruth Diamant; Ramón Espinasa-Pereña, and Manuel Fernández-Guasti

2011 Xochicalco: tlayohualchieliztli o cámara obscura. In 22 Congress of the International Commission for Optics: Light for the Development of the World, edited by Ramón Rodríguez-Vera, Rufino Díaz-Uribe, Proceedings of SPIE Vol. 8011, pp. 801190-1-801190-13, Mexico City.

Davies, Martin

1987 The Archaeology of Standing Structures. Australian Historical Archaeology 5:54-64.

De Saussure, Henri

1855 Découverte des ruines d'une ancienne ville située sur le plateau de Anahuac. Bulletin de la Société de Géographie XV:275-294.

Ellis, Bryan

1976 Surveying Caves, British Cave Research Association, Somerset, Great Britain.

Espinasa-Pereña, Ramón

2008 Field Trip Guidebook for the XII International Symposium of Vulcanospeleology, In Proceedings of the $X, X I$ and XII International Symposia on Vulcanospeleology, edited by Ramón Espinasa-Pereña and John J. Pint, pp. 275-305. Bulletin 19, Sociedad Mexicana de Exploraciones Subterráneas Boletin 7. Association for Mexican Cave Studies, Austin.

Ferriz, Horacio

1985 Caltonac, a Prehispanic Obsidian-Mining Center in Eastern México? A Preliminary Report. Journal of field Archaeology 12:363-370.

Ferriz, Horacio, and Gail A. Mahood

1984 Eruption rates and compositional trends at Los Humeros Volcanic Center, Puebla, Mexico, Journal of Geophysical Research 89:8511-8524.

Flores Gutiérrez, Daniel J.

2011 Anuario del Observatorio Astronómico Nacional. Instituto de Astronomía, Universidad Nacional Autónoma de México, Mexico City.

Galindo Trejo, Jesús

2001 La observación celeste en el pensamiento prehispánico. Arqueología Mexicana 8(47):29-35.

García Cook, Angel

2004 Cantona: ubicación temporal y generalidades. Arqueología, Segunda Epoca 33:91-108.

García Cook, Angel, and Yadira Martínez Calleja

2008 Las vías de circulación interna en Cantona. Arqueología, Segunda Epoca 38:125-160.

García Cook, Angel, and Beatriz Leonor Merino Carrión

1998 Cantona: urbe prehispánica en el altiplano central de México. Latin American Antiquity 9(3):191-216.

Haarmann, Erich

1910 Sobre una cueva en una corriente de lava en el estado de Puebla.Puebl. Boletín Sociedad Geológica Mexicana VII:141-143.

Iwaniszewski, Stanislaw

1999 El tiempo y la numerología en Mesoamérica. Ciencias 54:28-34.

Kauahikaua, Jim, David R. Sherrod, Katharine.V. Cashman, Christina Heliker, Ken Hon, Tari N. Mattox, and Jenda A. Johnson

2003 Hawaiian Lava-flow Dynamics During the Pu'u ‘O'oKupaianaha Eruption, A Tale of Two Decades. U.S. Geological Survey Prof. Paper 1676:63-88. 
Krickeberg, Walter

1977 Las antiguas culturas mexicanas. Fondo de Cultura Económica, Mexico City.

León-Portilla, Miguel 1986 El tiempo como atributo de los dioses. Universidad Nacional Autónoma de México, Mexico City.

Ministry of Tourism, Parks, Culture and Sport

2008 Avocational Archaeology Field Manual. 2nd ed. Revised. Heritage Resources Branch, Archaeological Resource Management, Ministry of Tourism, Parks, Culture and Sport, Saskatchewan, Canada.

Montenbruck, Oliver, and Thomas Pfleger

1994 Astronomy on the Personal Computer. Springer-Verlag, New York.

Montero García, Ismael Arturo

2004 Atlas arqueológico de la alta montaña mexicana. Comisión Nacional Forestal, Secretaría de Medio Ambiente y Recursos Naturales, Mexico City.

2011 Montañas y astros: una conjunción trascendente, In Legado astronómico, edited by Daniel J. Flores Gutiérrez, Margarita Rosado Solís and José Franco López, pp. 153-169. Instituto de Astronomía, Universidad Nacional Autónoma de México, Mexico City.

Moragas Segura, Natalia

1998 Cuevas ceremoniales en Teotihuacán durante el período Clásico. Boletín Americanista 48:179-195.

Morante López, Rubén B.

1990 En Xochicalco, el Popocatépetl marca el tiempo. México Desconocido 13 (164):28-32.

1995 Los observatorios subterráneos. La palabra y el hombre, Revista de la Universidad Veracruzana 94:35-72.

2001 Las cámaras astronómicas subterráneas. Arqueología Mexicana 8(47):46-52.

2010 La Pirámide de los Nichos de Tajín: los códigos del tiempo. Instituto de Investigaciones Estéticas, Universidad Nacional Autónoma de México, Mexico City.
Norton, Arthur P.

1973 Norton's Star Atlas. 16th ed. Gall \& Inglis, Edinburgh. Sease, Catharine

1994 A Conservation Manual for the Field Archaeologist. 3rd ed. Archaeological Research Tools 4. Institute of Archaeology, University of California, Los Angeles.

Soruco Sáenz, Enrique

1991 Una cueva ceremonial en Teotihuacán y sus implicaciones astronómicas religiosas. In Arqueoastronomía y etnoastronomía en Mesoamérica, edited by Johanna Broda, pp. 269-291. Serie Historia de la Ciencia y la Tecnología 4. Instituto de Investigaciones Antropológicas, Universidad Nacional Autónoma de México, Mexico City.

Sprajc, Ivan

2000a Problema de ajustes del año calendárico mesoamericano al año trópico. Anales de Antropología 34 :133-160.

2000b Astronomical alignments at Teotihuacán, Mexico Latin American Antiquity 11:403-415.

2001 Orientaciones astronómicas en la arquitectura prehispánica del centro de México. Colección Científica, Serie Arqueología. Instituto Nacional de Antropología e Historia, Mexico City.

Virlet d'Aoust, Pierre-Théodore

1865 Coup d'oeil général sur la topographie et la géologie du Mexique, et de l'Amerique centrale. Bulletin Societé Géologique de France 2 serie (V(XXII):14.

Wittich, Ernst

1921 Observaciones geológicas en la altiplanicie de San Juan de los Llanos, Puebla. In Memorias de la Sociedad Científica Antonio Alzate Tomo 39, pp. 597-613. Imprenta del Gobierno en el Ex-Arzobispado, Mexico City.

Submitted: August 8, 2011; Revised: April 17,2012, Accepted: October 14, 2012. 